\title{
Assessing Educators' Views on the Implementation of Technology Education in Selected Schools
}

\author{
Nokwali Mlandeli Philbert
}

Walter Sisulu University, South Africa

Mammen K. John

University of Fort Hare, South Africa

Maphosa Cosmas

University of Fort Hare, South Africa

Doi:10.5901/mjss.2014.v5n16p463

\section{Abstract}

Technology education is an important factor in every learner's education. It contributes to the intellectual and practical development of the learners to enable them to cope with the challenges of a technological society. Utilizing both quantitative and qualitative methodologies, this study sought to investigate the extent to which the learning and teaching of technology was implemented in schools in the Mthatha Education District in South Africa. A case study design was followed. A purposive sample of 20 senior phase educators was used in the study. A semi- structured questionnaire was employed to collect data. Quantitative data were analysed manually and qualitative data were analysed through content analysis. The results obtained revealed that the implementation of the technology learning area faced a number of challenges such as lack of resources especially the rural schools, lack of people who are knowledgeable on Outcomes-based education (OBE) or the OBE modes of learning and teaching technology and its assessment methods, ineffectiveness arising out of large and overcrowded classes, challenges originating from or as a consequence of redeployment and the rationalization of educators and the lack of human resource to assist in the implementation of technology. The study showed the need for the improved provision of supportive service from relevant subject advisors and their continuous contact with educators in order to offer advice and assistance in order to improve the quality of technology teaching and learning in schools. The professional knowledge and skills of subject advisors as well as educators need to be extended, refreshed and updated.

Keywords: Technology education, Learning outcomes, Curriculum implementation, South Africa

\section{Introduction and Background}

Technology has existed throughout history. As long as there have been people, there has been technology. Technology is part of our everyday lives, for example, in our kitchens, in the environment, in the industries and at play too. It has impacts on the way in which we manage our lives. Science and Technology were developed from the $17^{\text {th }}$ century onwards with the social justification that they were agents of liberation, both intellectually and materially (Van Rensburg, Myburgh \& Ankiewicz, 1996). Science was supposed to provide true knowledge and liberation from superstition and ignorance. Technology, giving some control over the material world, was supposed to liberate people from, among other things, excessive manual labour, hunger, poverty, inadequate housing and poor health. Science and Technology have been bundled together for many years (DoE, 2002).

Technology initiatives in schools in many countries have been a topic of research interest for the past thirty years and is of interest to several researchers recently too. Internationally, Technology Education (TE) has been gaining prominence in recent years (Tondeur, Van Braak \& Valcke, 2007; Selwyn, Potter \& Cranmer, 2009; Kolikant, 2009; Keengwe \& Onchwari, 2009; Davis, Preston \& Sahin, 2009; McGarr, 2009; Almekhlafi \& Almeqdadi, 2010; Lee, Cerreto \& Lee, 2010; Hall, 2010).

In South Africa too, TE has been gaining momentum. The need for TE in South Africa was outlined in the Green paper on Science and Technology in 1996. There was an agreement among industry and educators on TE as an important element or factor in every learner's education. Scientific papers dealing with the challenges and successes of 
TE in the African context are available (Van Wyk, 2002; Stevens, 2006; Brown \& Czerniewicz, 2006, 2007; Brown, Czerniewicz \& Pedersen 2008).

The school education in South Africa spans over 12 years and has two bands: General Education \& Training (GET) and Further Education \& Training (FET). GET and FET are from Grades R-9 (10 years) and Grades 10-12 (3 years) respectively. The GET band is sub-divided into Foundation (up to Grade 3), Intermediate (Grade 4-6) and Senior phase (Grade 7-9).

The core learning area of Technology in the GET band includes TE, Information Technology (IT), Technical Education and Applied Arts and Sciences. Technological advancement globally has surpassed all expectations and predictions. South Africa needs to access technology in order to compete internationally. TE, as a learning area aims to promote all aspects of technology, including planning, design and manufacturing. IT and TE were part of the core learning area of technology in Curriculum 2005 (C2005).

About two decades ago, Liao (1994:4) summarised the importance of technological literacy as follows:

\begin{abstract}
... all must become more technologically literate in order to make more informed decisions about personal choices as well as societal choices; and, democratic societies must use technology more intelligently in order to thrive in an increasingly competitive global economy.
\end{abstract}

Computers play a major role in TE since they are an integral part of modern technology. According to Pullias (1992:3) the emphasis in TE is on learning how a computer is used as a tool more than learning about computers. Potgieter (1998:3) observes that TE is concerned with the technological knowledge and skills as well as technological processes. TE involves understanding the use of technology and its impact on both the individual and society. It is ultimately designed to enable and equip learners to perform effectively in the technological environment in which they live and to stimulate them to contribute to its improvement. According to Hall (2010), most educators and learners in America have access to even laptops. However, the South African educators and learners are much less resourced. As is common knowledge, achieving success in any type of change is always a challenge and this is more so when it comes to technology and TE. In TE also, the greatest shortage has always been that of resources as usual in every project or organization. This was clearly articulated by Moore (2005) by stating that every company (even in the United Kingdom) will at one time or another complain of shortage of resources.

TE in South Africa has not been an exception in the shortage of resources. Stevens (2006) and Williams (2009) concur and state that South Africa faces challenges in terms of resources to effectively implement TE. For example, Williams (2009) refers to Stevens (2006) who observed that South Africa has developed a national Technology education curriculum with a social reconstructivist approach that was scheduled to be implemented in 2006. Williams (2009: 241) quotes Stevens (2006) for emphasis as follows:

It has technological literacy as its overarching goal for students, and contains some innovative and unique elements such as 'appropriate indigenous technologies' as one of the content areas ... However, largely due to the apartheid policies during the history of South Africa, many rural schools have very few resources and it will take many years before all schools enjoy a basic level of technology resources and equipment...

According to Cohen, Manion and Morrison (2007), historical research can provide us with an insight into how the present has come about. Tracing back the history, at the Jerusalem International Science and Technology Conference (JISTEC) which was held in January 1996 under the auspices of UNESCO, there was a general consensus that the quality of life in society was linked to the people's understanding, effective use of present technology and creative development of new technologies. According to Ort-step Institute (1995), Ankiewicz (1995) and UNESCO (1997), TE is a subject on its own epistemology and consists basically of the following attributes:

- Knowledge items such as literacy, technology, scientific principles and concepts, mathematical terms and models, environmental studies, agriculture, materials and economics.

- Skills items such as observation, design and construction, data collection, analysis, interpretation, research skills, technological and cognitive skills, making and manipulating skills, teamwork, communication, graphic communication and safe work habits.

- Thinking skills such as critical thinking, reasoning, decision making, evaluation, analytical skills, problem solving, positive attitudes and values, creative and innovative thinking skills.

In general, Technology is an engine-house for the development and prosperity of any nation in terms of the historical, cultural, social and economic perspectives (Poon, 1994; Potgieter, 1998). As such, efforts to establish TE as a learning area, especially for a developing country like South Africa, could not have been overemphasized. Developed 
countries such as Britain, Japan, the US, Australia and Canada and developing countries such as Nigeria, the Philippines and Korea have prioritised technology. Technology makes the world a global village. For South Africa to be among the progressing nations, it had to embark on educating the nation about technologies. However, Van Wyk (2002) observes that in an expanding globalised world, learners can become easily alienated from what is taught in science and technology as well as the way in which it is taught. He recommends integration of indigenous knowledge systems with TE and South Africa's present syllabus content does so..

Due to the perceived congestion of the curriculum and the change in paradigm, TE was wrongly thought of as an excess learning area through the recommendations of the review committee (Chisholm, 2000). For reasons based on its importance and necessity, TE was then reinstated in the curriculum. With the implementation of curriculum 2005 (C2005) (based on the principles and premises) of Outcomes Based Education (OBE) in 1998, TE became a reality in South Africa. With the introduction of the new technology learning area, South Africa has been brought into line with developments worldwide.

The National Curriculum Statement (NCS) in South Africa (NCS, 2002:14) was in line with these sentiments regarding TE when it stated that technology learning area contributed towards learner's technological literacy by giving them opportunities to: appreciate the interaction between technology, society and the environment, develop and apply specific skills to solve technological problems and understand the concepts used in technology and use them responsibly to solve technological problems. Stevens (2006) discusses the implications of TE for teacher education in South Africa. Brown and Czerniewicz (2007) investigated the relationship between students' access to ICTs for learning. Solomon (1993:38) states that "technology and consequently Technology Education is an experience that no person should either miss or be led to believe that it is unconnected with Science."

The recent Curriculum and Assessment Policy Statement (CAPS) published by the national South African government's Department of Basic Education (DBE), reinforced the learning and teaching of technology and support for TE right from the beginning of the Intermediate phase, i.e., grade 4 (see CAPS, 2011). This is surely a progressive development from NCS and the Revised National Curriculum Statement (RNCS). Each term includes a Technology strand which is organised to promote clear progression of concepts across the Grades and in the phase. Conceptual links between the Science and Technology in the different topics are delineated. At least two Technology strands are to be developed in each Grade. The technology strands from grades 4 to 6 are Structures, Processing and Systems and Control and this provides a good basis to progress to the senior phase technology content. In order to give a solid foundation to technology, three specific aims in Natural Sciences and Technology module are emphasised by CAPS (2011) intermediate phase to firmly ground Technology for the senior phase and these are:

- 'Doing Science and Technology'-Learners should be able to complete investigations, analyse problems and use practical processes and skills in designing and evaluating solutions. This means that learners plan and do simple investigations and solve problems that need some practical ability. There are attitudes and values that underpin this ability.

- 'Understanding and connecting ideas'-Learners should have a grasp of scientific, technological and environmental knowledge and be able to apply it in new contexts. The main task of teaching is to build a framework of knowledge for learners and to help them make connections between the ideas and concepts in their minds - this is different to learners just knowing a lot of facts. When learners do an activity, just answering the set questions is not enough. Discussion must relate to previously acquired knowledge and experience and connections must be made.

- 'Science, Technology and Society'-Learners should understand the practical uses of Natural Sciences and Technology in society and the environment and have values that make them caring and creative citizens. Science and Technology learnt at school should produce learners who understand that school science can be relevant to their lives outside of school. Issues such as improving water quality, growing food without damaging the land, and building energy-efficient houses are examples of everyday applications. Similarly, Science and Technology can lead earners to a range of career and job possibilities. An appreciation of the history of scientific discoveries and technological solutions, and their relationship to indigenous knowledge and different world views, enriches our understanding of the connections between Science, Technology and Society.

Amongst others, the following major process and design skills for technology are also emphasized:

- Designing: showing (e.g. by drawing) how something is to be made taking into account the design brief, specifications and constraints;

- Making/constructing: building or assembling an object using appropriate materials and tools and using skills such as measuring, cutting, folding, rolling, gluing; 
- Evaluating and Improving products: using criteria to assess a constructed object and then stating or carrying out ways to refine that object;

- Communicating: using written, oral, visual, graphic and other forms of communication to make information available to other people.

Teachers' use of information and communication technologies (ICT) has an important role in education in the $21^{\text {st }}$ century (Haydon \& Barton, 2007; Somekh, 2008; UNESCO, 2008). Realizing this, many countries and regions are designing ICT related teacher training in Africa (Evoh, 2007). UNESCO (2008) has recently published guidance for this. Research has established that effective ICT teacher training is an important pillar for successful integration and sustainability of ICT in education (Culp, Honey, \& Mandinach, 2003; Haydon \& Barton, 2007; Somekh, 2008). Therefore, given the demand, research to inform the design of effective ICT teacher training is urgent. A paper by Lawless and Pellegrino (2007) on technology-related professional development also calls for a study that compares models of technology-related professional development and the study of scaling such interventions from local to a national level.

\section{Research Question}

This study sought to answer the following research question:

What are the challenges for the implementation of technology learning area in the Senior Phase?

\subsection{Research sub questions}

Drawing from the main research question, the following sub research question were posed;

- What support does the Department of Education give to educators?

- To what extent have the objectives of implementing the technology learning area been achieved?

- What suggestions do educators have to improve implementation of technology education?

\subsection{Research Objectives}

The study sought to establish challenges in the implementation of technology education in selected schools by ascertaining the nature of support offered to educators by the Department of Education, the extent to which technology education goals were achieved and suggestions educators had on the improvement of the implementation of technology education.

\section{Research Methodology}

The study employed a combination of both quantitative and qualitative methodologies and adopted a case study design. A semi-structured questionnaire was utilized to collect data from a purposive sample of 20 educators drawn from 20 Junior Secondary Schools (10 rural and 10 urban) from Mthatha Education District. A pilot study was conducted to enhance validity and reliability of the questionnaire. According to Cohen, Manion and Morrison (2007) a pilot study serves to check the clarity of the questionnaire items, to eliminate ambiguities or difficulties in wording, to gain feedback on the type of questions and its format, to check time taken to complete the questions and its format and also to generate categories from open ended responses to use as categories for closed responses-modes e.g. rating scale items. For the above reasons the researchers conducted a pilot study on three educators and three learners making use of the questionnaire a week before the final administration of the questionnaires. The feedback from the pilot study helped to fine-tune and improve the questionnaires. An expert (a university lecturer with experience in research) was requested to make inputs and his inputs were very helpful.

Letters requesting completion of questionnaire were distributed to various schools. The lead researcher personally visited each school involved in the study and handed the questionnaires to the concerned educators at each school. He explained the purpose of research to each member of the sample and indicated that they were free not to participate in the study or withdraw from it any time. All those approached were willing to participate in the study. A $100 \%$ return rate for the questionnaire was realized.

Permission to conduct research was obtained from relevant authorities. As stated earlier, the lead researcher had explained the purpose of the research to all participants and requested their voluntary participation. No one objected. The respondents answered anonymously. Each participant signed the informed consent form. 


\section{Data Analysis, Interpretation, Results and Discussion}

The presentation of data in the form of tables simplifies analysis and interpretation. The purpose of data analysis was to translate information gathered into a form which enabled the researchers to interpret the data. The data were analysed manually and were represented in the form of tables. Major findings were identified and interpreted.

\subsection{Data from educators}

\subsubsection{Biographical variables of educator respondents}

Table 1: Biographical variables of educator respondents

\begin{tabular}{|l|c|c|c|}
\hline Biographical Variable & Description & Number & Percentage \\
\hline \multirow{3}{*}{ Age } & $26-30$ & 1 & 5 \\
\cline { 2 - 4 } & $31-35$ & 4 & 20 \\
\cline { 2 - 4 } & 36 and above & 15 & 75 \\
\hline \multirow{3}{*}{ Gender } & Male & 11 & 55 \\
\hline \multirow{3}{*}{ Position in school } & Female & 9 & 45 \\
\hline \multirow{3}{*}{ Subject Specialisation } & Educator & 15 & 75 \\
\cline { 2 - 4 } & Head of department & 4 & 20 \\
\cline { 2 - 4 } & Principal & 1 & 5 \\
\hline \multirow{3}{*}{ Experience in teaching technology } & Languages & 4 & 20 \\
\cline { 2 - 4 } & Mathematics & 4 & 20 \\
\cline { 2 - 4 } & Commerce & 1 & 5 \\
\cline { 2 - 4 } & Technology & 11 & 55 \\
\hline \multirow{3}{*}{ Self-assessment in teaching Technology } & 1 year & 2 & 10 \\
\cline { 2 - 4 } & 2 years & 4 & 20 \\
\cline { 2 - 4 } & 3 years and above & 14 & 70 \\
\cline { 2 - 4 } & Fair & 9 & 45 \\
\cline { 2 - 4 } & Good & 6 & 30 \\
\cline { 2 - 4 } & Very Good & 4 & 20 \\
\hline
\end{tabular}

With the above data, one can conclude that technology was mostly (75\%) taught in the district by educators at 36 years and above. The gender data shows balance between male and female educators. Often it is said that technology is a man's domain but with the present data obtained from schools in Mthatha, women are almost equally engaged as technology educators. Out of the respondents, 15 out of 20 (75\%) who taught technology were educators at post-level 1 (the lowest rung of professional ranks) who were not directly involved in the broader school management. $20 \%$ were Heads of the department (HoDs). There was also one Principal who taught technology learning area. The reason for this could be due to the shortage of personnel with expertise, training or interest in the learning area. Nevertheless, it was interesting to see that at least one Principal also was involved in teaching TE. Exactly 55\% of educators who were handling the technology learning area had specialized in the field of technology. Data also showed that $20 \%$ each of the educators had specialized either in languages or mathematics. Only $5 \%$ of the educators had specialized in commercial subjects. It was heartening to note that more than half the group of educators had specialization in TE which was rather a new learning area. Considering that the schools were mainly in the rural area of the Transkei region in South Africa, this was encouraging. The above table shows that $70 \%$ of educators had been teaching technology for more than three years. $20 \%$ of the educators had two years' experience while only $10 \%$ of the educators had less than two years' experience. This data, therefore, showed that technology was facilitated mostly by experienced educators in facilitating TE. The above table portrays educators' self-assessment of their performance. Only $5 \%$ claimed to be excellent. $20 \%$ claimed to be very good and $30 \%$ claimed to be good. $45 \%$ of the educators assessed their performance was fair. By collapsing those who gave themselves a grade of 'very good' and above, it can be seen that 55\% (11 out of 20) were in the 'very good' and above category. The overall data on self-assessment are surely encouraging. 


\subsection{Educators' responses on te curriculum, implementation and challenges}

\subsubsection{Data gathered from the survey on educators' responses on the TE curriculum, implementation and challenges}

This section provides educators' responses on the TE curriculum, implementation and challenges.

Table 2: Educators' responses on the extent to which they agreed or disagreed with the given statement.

\begin{tabular}{|c|l|c|c|c|c|c|c|}
\hline \multirow{2}{*}{ No. } & Items & \multicolumn{3}{|c|}{ Responses } \\
\cline { 3 - 6 } & & SD & D & NO & A SA & Total \\
\hline 1 & In In technology education, practical work enhances rnilearning more than written work. & 1 & 2 & & 6 & 11 & 20 \\
\hline 2 & The government has provided adequate textbooks for technology. & 2 & 7 & 3 & 8 & 0 & 20 \\
\hline 3 & Learners are motivated and positive towards technology education. & 2 & 4 & 3 & 7 & 4 & 20 \\
\hline 4 & There is lack of educator training in technology education & 0 & 1 & 2 & 7 & 10 & 20 \\
\hline 5 & Educators' attitude towards the implementation of technology education is negative. & 2 & 6 & 0 & 9 & 3 & 20 \\
\hline 6 & Cultural differences play a part in the implementation of technology education. & 0 & 6 & 6 & 5 & 3 & 20 \\
\hline 7 & Teaching technology education is demanding. & 0 & 0 & 0 & 8 & 12 & 20 \\
\hline 8 & Educators do not know what the technology learning area really entails. & 3 & 3 & 2 & 8 & 4 & 20 \\
\hline 9 & In technology learning area, most lessons are child-centred. & 1 & 4 & 1 & 8 & 6 & 20 \\
\hline 10 & There are enough subject advisors to assist and support educators in the implementation of technology. & 13 & 5 & 1 & 1 & 20 \\
\hline
\end{tabular}

From Table 2, the strongly disagree (SD) and disagree responses (D) were collapsed into disagree (D). Similarly, the agree $(A)$ and strongly agree (SA) responses were collapsed into agree $(A)$ to generate Table 3 to summarise the data.

Table 3: Educators' agreement or disagreement with given statements

\begin{tabular}{|c|c|c|c|c|}
\hline Items & Disagree (D) & No opinion (N) & Agree (A) & Total \\
\hline 1 & $3(15 \%)$ & 0 & $17(85 \%)$ & 20 \\
\hline 2 & $9(45 \%)$ & $3(15 \%)$ & $8(40 \%)$ & 20 \\
\hline 3 & $6(30 \%)$ & $3(15 \%)$ & $11(55 \%)$ & 20 \\
\hline 4 & $1(5 \%)$ & $2(10 \%)$ & $17(85 \%)$ & 20 \\
\hline 5 & $8(40 \%)$ & 0 & $12(60 \%)$ & 20 \\
\hline 6 & $6(30 \%)$ & $6(30 \%)$ & $8(40 \%)$ & 20 \\
\hline 7 & 0 & 0 & $20(100 \%)$ & 20 \\
\hline 8 & $6(30 \%)$ & $2(10 \%)$ & $12(60 \%)$ & 20 \\
\hline 9 & $5(25 \%)$ & $1(5 \%)$ & $14(70 \%)$ & 20 \\
\hline 10 & $18(90 \%)$ & $1(5 \%)$ & $1(5 \%)$ & 20 \\
\hline
\end{tabular}

\subsection{Analysis and interpretation}

\subsubsection{Item 1: In technology education, practical work enhances learning more than written work.}

The majority (80\%) of the respondents agreed with the statement. Only a minority of the respondents (15\%) disagreed with the statement. From the findings, it is evident that many of the technology educators are of the opinion that technology is a practical rather than theoretical subject. According to Monau (1997), in OBE, learners "perform their skills" which means that the learners are required to do something that will demonstrate that learning has taken place.

\subsubsection{Item 2: The government has provided adequate textbooks for technology.}

It can be seen that $45 \%$ of the respondents disagreed with the statement, $40 \%$ agreed and $15 \%$ were uncertain. The data show that educators were almost equally divided in their opinion regarding whether the government supplied adequate textbooks for the implementation of the technology learning area. It became therefore clear that educators in some schools were experiencing problems due to inadequacy of textbooks in the implementation of TE. It appeared that although the DoE had been trying its level best by subsidizing textbooks to schools, the distribution remained uneven. This meant that schools which did not receive textbooks needed to follow up the matter on time with DoE in order to 
improve the quality of service constantly. Also, DoE needs to take proactive action to avoid similar situations in the future.

\subsubsection{Item 3: Learners are motivated and positive towards technology education.}

Most of the respondents (55\%) agreed with the statement. However, 30\% disagreed and 15\% were uncertain. According to the DoE (1997: 84), an understanding of technology education should contribute to more positive attitudes towards perceptions and aspirations to technology-based careers. The data show that only about half of the sample agreed with the statement and thus is a matter of concern. Deliberate efforts to promote intrinsic motivation need to be encouraged. Debates and discussions on disadvantages and advantages of technology and TE together with assignments on technology-related topics may promote positive attitudes amongst learners.

\subsubsection{Item 4: There is lack of educator training for technology education.}

The vast majority of respondents (85\%) agreed with the statement. Out of the total respondents (5\%) disagreed and $(19 \%)$ were uncertain. This finding is in agreement with the observation that there has been very little teacher training on didactics and assessment with respect to C2005 (Monau, 1997:2).

Jansen (2001:3) emphasized the lack of effective teacher development strategies, Ankiewicz (1995:4) also expressed concern over the shortage of technological expertise in South Africa. There is an ongoing teacher training because technology is still new to South Africa. This brought the researchers to the conclusion that most educators needed training in the form of workshops. The few workshops and crash courses which were delivered lacked the depth and breadth to equip the educators in order to properly implement this learning area. Educators' dissatisfactions are evident in the data since only $5 \%$ reported that there was educator training. It could also be that there were such trainings but the quality was poor and hence educators hold a view that there was inadequate training.

\subsubsection{Item 5: Educators' attitudes towards the implementation of technology education are negative.}

Most of the respondents (60\%) agreed with the statement and 40\% disagreed. Based on these figures one can conclude that the general attitudes of educators towards technology education is negative. Low morale, low motivation and lack of understanding of what TE really entails could contribute to teachers' negative attitudes. This is surprising when $55 \%$ of educators had technology as specialization in their training. This could also mean that there are challenges that are brought about by the new education dispensation. Schiller (1991) emphasizes the role of heads of schools in implementing computer education as part of TE in schools. Ankiewiecz and Swart (2001) suggest that good in-service training programmes and skills training might be the answer in order to cultivate more positive attitudes.

\subsubsection{Item 6: Cultural differences play a part in the implementation of technology education.}

When $40 \%$ of the respondents agreed with the statement, $30 \%$ disagreed and $30 \%$ were uncertain. This data imply that most of the respondents believed that cultural differences do play a role in the implementation of technology education. Specific outcome 5 for the technology learning area stipulates the need for learners to "demonstrate an understanding of how different societies create and adapt technological solutions to particular problems (DoE, 1997: 84). The adaptation of technological solutions to particular problems in different societies is an acknowledgement of the use of cultural differences in the implementation of technology. The revelation from the data that only $40 \%$ educators could acknowledge the significance of DoE's view transmits a cause for concern which demands proactive steps to improve upon the challenge needs to be taken through in-service training.

\subsubsection{Item 7: Teaching technology is demanding}

All of the respondents (100\%) agreed with the statement. This could mean that they perceived the curriculum as already overloaded and that the inclusion of technology education was making matters worse (Chisholm, 2000:20). This could also mean that more time and facilities are needed for TE since it is a new learning area and there is a lot of practical work in it. Some educators are battling to understand it and empowering support should be given to them in order for them to cope with the demands from TE. 


\subsubsection{Item 8: Educators do not know what the technology learning area really entails.}

The data show that $60 \%$ of the respondents agreed with the statement, $30 \%$ disagreed and (10\%) were uncertain. Most educators claim that they have limited knowledge. These responses could be due to the respondent's inadequate familiarity with the TE curriculum. This inadequacy of knowledge in technology education was confirmed by the initial research by Compton and Harwood (2003). They mention that educators experience problems in developing programmes in the technology education that support learner's learning and provide learners with the opportunity to excel. Educators' limited knowledge of TE curriculum causes this. The respondents who indicated that they know what the technology learning area really entails (30\%) could have read the C2005 documentation with specific reference to the technology learning area. Only $5 \%$ were uncertain and no conclusion could be reached as to why this was so.

\subsubsection{Item 9: In technology learning area, most lessons are learner-centred.}

Most lessons are learner-centred and this is confirmed by the responses of about $70 \%$ of the respondents who agreed with the statement. Only 25\% disagreed and $5 \%$ were uncertain. The education of the learner should be holistic. Learners have been traditionally used to teacher-centred lessons where teachers where always seen as source of information.

Technology learning area makes imperative for both learners and educators to engage in do research. Parrette, Hourcade \& Heiple (2000) share a similar view when they state that education is emphasizing student activity and is thus making use of constructivist strategies where students construct their own knowledge bases and educators do less direct instruction and rather facilitate the learning process. The result is that learners are also able to assist each other.

\subsubsection{Item 10: There are enough subject advisors to assist and support educators in the implementation of technology.}

Most of the respondents $90 \%$ disagreed with the statement. Out of the remainder, $5 \%$ agreed and $5 \%$ were uncertain. The vast majority of the respondents opined that there is a lack of assistance from the DoE in the form of subject advisors to equip educators with all the necessary skills and instructional methods expected.

\subsection{Data gathered through open-ended questions}

Question 1 sought to gather data about the main problems which limit educators' success in the teaching of technology and question 2 sought to gather information about the steps to be taken in order to improve the implementation process. Question 3 sought to know about the kind of support given by the DoE to assist educators and question 4 sought to gather educators' general feelings about the implementation of technology learning area in schools. Main problems which limited educators' success in the teaching of technology were established to be:

- Lack of resources, equipment, or materials

- Lack or inadequacy of workshops

- Provision of relevant and appropriate resources.

- Inadequate departmental support

- Lack of adequate teaching time for technology education

- Lack of time for practical work.

- Unavailability of subject advisors to support teachers

The data should serve as an eye-opener for Department of Education and school Principals and serve as a guide to plan short-term, medium-term and long-term proactive interventions to enhance the teaching of technology in schools.

\section{Conclusions}

TE is a new learning area and both educators and learners are still grappling with understanding what exactly it entails. Educators are confident of their ability to teach but the problem is using OBE instructional methods effectively in teaching. Educators claim that the training given by the DoE was inadequate.

The researchers' visits to schools revealed that some schools did not have electricity. TE does not end with the design of policies. Educators expressed their concern regarding the inadequate support they receive from DoE. According to Pudi (2002) curriculum planning and design is theory but implementation means converting the theory into practice. Making the two coincide sometimes lead to new problems that the curriculum designer as theorists did not 
anticipate. According to Pudi, access to TE is often inhibited by the realities such as poverty, budgetary constraints and lack of resourceful thinking from the policy makers or the schools or even the educators and the learners themselves. The need for support and effective workshops were highlighted to boost educator confidence to facilitate productive learning and teaching. The curriculum planners and educators as implementers of the curriculum should have a common understanding and vision of what curriculum should achieve. Furthermore, educators, needs to be clear as to what are the objectives of this learning area.

The triangulated data highlighted the following: Inadequacy or lack of resources, equipment, materials, space, classrooms or technical rooms; the need to lead learners to technical skills to cope with a technologically advancing global context; inadequate support from DoE in capacity building of educators and in the supply of learner support materials to each and every school and finally, there was a call for more classroom and laboratory time for TE.

The Government needs to take cognisance of educators' interests, abilities, attitudes and skills. The implementation of technology education requires an integrated approach. Gravett (1995) as well as Lubisi, Parker and Wadekind (1999:97) stress that education of the learner should be holistic. There is a long way to go before the objectives of TE learning area could be achieved.

Education has to be everybody's concern. Working together of all stakeholders like department officials, educators, parents, NGO's and learners could catalyse the effective implementation of technology. Working together to build an education and training system for the $21^{\text {st }}$ century would ensure the best future of South African citizens.

\section{Recommendations}

First and foremost, the technology educators and subject advisors must be involved in the design of technology curriculum and drawing up of policy. In constructing a policy, curriculum planners or developers should have an idea of the 'as is' context of the senior phase in rural schools in South Africa to gauge the resources needed to effectively implement the curriculum and take proactive actions. In-service training for TE should become not only more frequent, but also more effective. The uneven distribution of learner support material to schools should be urgently addressed. Further related studies should be carried out to investigate more challenges. Electricity supply to all schools needs to be supported to assist effective delivery of TE.

\section{References}

Almakhlafi, A.G. \& Almeqdadi, F. A. (2010). Teachers perception of technology Integration in the United Arab Emirates school classrooms. Educational Technology \& Society, 13 (1): 165-175.

Ankiewicz, P.J. (1995). The planning of technology education for South African Schools. International Journal of Technology and Design Education, 5: 1-10.

Ankiewiecz, P.J. \& De Swart, A.E. (2001). Principles, Methods and Techniques of Technology Education 11, Study guide. Rand Afrikaans University: Johannesburg.

Brown, C. \& Czerniewicz, L. (2007). If we build it will they come? Investigating the relationship between students access to and use of ICTs for learning. South African Journal of Higher Education, 21(6): 732-747

Brown, C., Czerniewicz, L. \& Pedersen, J. (2008). Doing it for themselves. How South African students learn to use computers for their studies. $10^{\text {th }}$ Annual Conference of www applications. Cape Town. 3-5 September.

CAPS (2011). Curriculum and Assessment Policy Statement - Grades 4 - 6. Natural Science and Technology. Pretoria: Department of Basic Education

Chisholm, L. (2000). A South African curriculum for the twenty first century: report of review committee on curriculum 2005. Education Portfolio Committee: Cape Town.

Cohen, L., Manion, L. \& Morrison, K. (2007). Research methods in Education, (6th Edition), London: Routledge Falmer College.

Compton, V.J. and Harwood, C.D. (2005) Progression in Technology Education in New Zealand: Components of practice as a way forward. International Journal of Design and Technology Education. 15 (3), 253-287.

Culp, K., Honey, M. \& Mandinach, E. (2003). A retrospective on twenty years of education technology policy. American institutes for research (US Department of Education, Contract NO. ED-01-CO-0026/0017). Washington, DC: US Department of Education

Davis, N, Preston, C, \& Sahin I. (2009). Training teachers to use new technologies impacts Life on screen: Identity in the age of internet. multiple ecologies: Evidence from a national initiative. British Journal of Educational Technology, 40, (5): 861- 878.

DoE, (1997). Policy Document. Senior Phase (Grade 7 to 9) Eastern Cape: Bisho.

DoE, (2002). Revised National Curriculum Statement: Grades R-9. Pretoria: Government Printers.

Evoh, C. (2007). Policy networks and the Transformation of Secondary Education through ICTs in Africa. International Journal of Education and Development using ICT, 3 (1): 272.

Gravett, S. (1995). The assessment of learning guidelines and methods. Monograph, Johannesburg: RAU.

Hall, G. E. (2010). Technology Achilles Heel : Achieving high quality implementation. Journal of Research on Technology in education, 
42 (3): 231-253.

Haydon, T. \& Barton, R. (2007). First do no harm: developing teachers ability to use ICT in subject teaching-some lessons from UK. British Journal of Education Technology, 38 (2): 365-368.

Jansen, J.D. (2001). Seven threats facing teachers and teaching. The Educators' Voice: the paper for teachers by teachers, January/February, 5 (1): 5. http://www.sadtu.org.za. Retrieved: April 11, 2010.

Keengwe, J., Onchwari, G. (2009). Technology Onchwari, Technology and Early Childhood Education A Technology Integration Professional Development Model for practicing teachers . Journal of Early childhood Education, 37: 209-218.

Kolikant, D.Y. (2009). Digital students in a Book-Orientated School: Students' perceptions of school and the usability of digital Technology in Schools. Educational Technology \& Society, 12 (2): 131-143.

Lawless, K.A. \& Pellegrino, J. W. (2007). Professional Development in integrating technology into teaching and learning: knowns unknowns, and ways to pursue better questions and answers. Review of Educational Research, 77 (4): 575-614.

Lee, J. Cerreto F.A., Lee, J. (2010). Theory of planned behavior and teachers decisions regarding use of educational technology. Educational Technology \& Society, 13(1): 152-164.

Liao, D. 1994. Literacy and technology: Deictic consequences for literacy education in an information age. Mahwah: N. J. Earlbaum.

Lubisi, C., Parker, B.,Wadekinde, V. (1999). Understanding outcomes based education: teaching and assessment in South Africa: learning guide. Cape Town: Oxford University Press.

McGarr, O. (2009). The development of ICT across the curriculum in Irish schools: A historical perspective. British Journal of Educational Technology. 40(6): $1091-1108$.

Monau. A. (1997). In OBE, learners perform their skills. The Teacher, 2: 11.

NCS (2002). National Curriculum Statement. Department of Education: Pretoria.

Ort-step Institute, (1995). Proposal for primary school technology curriculum. Johannesburg: Ort-step Institute.

Parette, D., Hourcade, C. \& Heiple, G. (2000). The motivational effect of ICT on pupils. Nottingharm: DFES.

Poon, A. (1994). Tourism, technology and competitive strategies. Wallingford: Cab International. Pratt, J. 1980. Evidence and proof in documentary research : Some specific problems of documentary research. Sociological Review, 29(1): 31-52.

Potgieter, C. (1998), Technology A: Only study guide for FDETE1-A, Pretoria: UNISA.

Pudi, T.I. (2002). Teacher attitudes in the implementation of the learning area Technology, Unpublished doctoral thesis: Pretoria: Unisa.

Pullias, D. (1992). What is technology education? The technology teachers, 51 (4): 3-4.

Selwyn, N., Potter, J. \& Cranner, S. (2009). Primary pupils' use of information and Communication technologies at school and home. British Journal of Educational Technology, 40(50): 919-932.

Solomon, J. (1993). Teaching Science, technology and Society. Buckingham: University Press.

Somekh, B. (2008). Factors in affecting teachers pedagogical adoption of ICT in J. Voogt \& G. Knezek (eds), International handbook of information technology in primary and secondary education. Amsterdam: Springer.

Stevens, A. (2006). Technology teacher education in South Africa. In M.J. de Vries \& I. Mottier (Eds), International handbook of technology Education. Rotterdam: Sense Publishers.

Tondeur, J., Van Braak, J. \& Valcke, M. (2007). Curriculum and use of ICT in education: two worlds apart? British Journal of Educational Technology, 38: 962-976.

UNESCO. (United Nations Educational, Scientific and Cultural Organization). (1997). Gender and science \& technology Education. UNESCO International Science, Technology \& Environmental Education Newsletter, xxii(1)

UNESCO (United Nations Educational, Scientific and Cultural Organization). (2008). ICT competency standards for teachers-Towards ICT skills for teachers. Paris UNESCO

Van Rensburg, S.J., Myburgh, C.P.H. \& Ankiewicz, P. (1996). Curriculum development for technology Education in South Africa: gender issues. Paper presented at the GASAT conference, Ahmedabad, India, 5-10 January.

Van Wyk, J. (2002). Indigenous knowledge systems: Implications for natural science and technology teaching and learning. South African Journal of Education, 22 (4): 305-312.

Williams, P.J. (2009). Technological literacy: A multliteracies approach for democracy. Journal of Technology Design Education, 19: 273254. 